Науменкова С. В., д.е.н., професор

Київський наиіональний університет імені Тараса Шевченка м. Київ, Україна

Міщенко С. В., д.е.н., професор ДВНЗ «Університет банківської справи» м. Київ, Україна

DOI: https://doi.org/10.30525/978-9934-26-068-1-32

\title{
ПРОБЛЕМИ ЦИФРОВОЇ ТРАНСФОРМАЦІЇ БАНКІВСЬКОЇ СИСТЕМИ
}

У сучасних умовах у банківських системах більшості країн світу відбуваються значні організаційні та технологічні зміни, обумовлені процесами цифровізації економіки, які знаходять свій прояв у використанні цифрових технологій і каналів комунікації, цифрових форм продажу продуктів і послуг, а також у створенні цифрових та онлайн-банків, наслідком чого $є$ використання нових джерел інформації, алгоритмів оброблення даних, критеріїв оцінки та прийняття управлінських рішень у діяльності банків [1, c. $28 ; 2$, c. $19 ; 3$, c. 83].

Цифровізація ринку банківських послуг призводить до суттєвих змін у технологіях i методах надання послуг; з'являються нові фінансові продукти та послуги, які неможливо було запропонувати ринку та реалізувати 3 використанням традиційних технологій. Використання нових комунікаційних $\mathrm{i}$ цифрових технологій принципово змінюе характер діяльності банку та його взаємовідносини 3 клієнтами. Основною формою банківського обслуговування клієнтів у більшості країн світу стають мобільні платежі та онлайн-банкінг. Поширення набуває використання блокчейна та хмарних технологій, «Інтернету речей», штучного інтелекту, роботизованих радників, технологій віддаленої ідентифікації клієнтів, автоматизація процедур виявлення шахрайства та операційних ризиків тощо. На ринку банківських послуг активно починають працювати небанківські установи, фінтех-компанії та приватні особи, посилюється 
конкуренція між фінансовими установами та платіжними системами $[4$, с. $23 ; 5$, с. $191 ; 6$, с. 52$]$.

Використання цифрових технологій дає можливість банкам суттєво знизити свої витрати на надання банківських послуг, використовувати нові джерела одержання доходів, збільшувати частку на ринку, поліпшувати імідж і характер взаємовідносин 3 клієнтами. Крім того, в умовах невизначеності цифрова трансформація стає важливим чинником зниження асиметрії фінансової інформації та сприяє підвищенню рівня фінансової інклюзії, що має надзвичайно важливе значення для підтримки фінансової й соціальної стабільності та підвищення рівня довіри населення до банківської системи країни [7, с. $68 ; 8$, с. 59 ; 9, с. 8].

Упродовж останніх десятиліть у світі відбувається підвищення рівня концентрації банківського капіталу та зменшення кількості банків. Так, 31990 р. до 2020 р. лише в США кількість банків зменшилась майже втричі, а кількість відвідувачів банківських офісів за останні п'ять років - на $60 \%$ [9, с. $61 ; 10$, с. $23 ; 12$, с. 8$]$. Така ж ситуація спостерігається і в інших країнах. Наприклад, в Україні в 2020 р. порівняно з 2013 р. кількість банків зменшилась в 2,4 рази, а кількість їхніх підрозділів - у 2,8 рази. При цьому в розрахунку на один банк кількість підрозділів у 2020 р. порівняно з 2018 р. зменшилась зі 110,5 до 96,4 од., тобто, на 12,8\%.

Згідно 3 оцінками фахівців, головними завданнями банків в умовах цифровізації економіки $\epsilon$ : розширення дистанційного обслуговування клієнтів, надання послуг у цифровому форматі, багатоканальне залучення клієнтів, покращення клієнтського досвіду та взаємодії з банками, розроблення нових програм для обслуговування клієнтів, що потребує належної методичної та інформаційної підтримки процесу цифрової трансформації банків 3 боку регуляторів [13, с. 47].

Поряд 3 формуванням цифрової надбудови у вигляді digitalпідрозділів традиційних банків поширення набуває процес створення та розвитку банків i фінансових установ нового організаційно-технологічного типу - цифрових і онлайн банків, основними ознаками яких $\epsilon$ використання цифрових процесів $\mathrm{i}$ 
цифрових каналів надання послуг та взаємодії 3 клієнтами. На початок 2021 р. в світі нараховувалось уже понад 1000 цифрових та онлайн-банків. До найбільших цифрових банків належать Citibank, JPMorgan Chase, HSBC, а до найбільших онлайн-банків Revolut та Тінькофф Банк. Перший онлайн-банк - Monobank у 2017 р. було створено й в Україні.

Корпорація IBM виокремлює чотири моделі створення та функціонування цифрових та онлайн-банків.

1. Модель А - цифровий банківський бренд, виокремлений 3 традиційного «материнського» банку.

2. Модель В - традиційний банк, який з метою надання послуг і продажу банківських продуктів використовує цифрові канали.

3. Модель С - новий цифровий банк, який $є$ дочірньою компанією традиційного банку.

4. Модель D - новий самостійний цифровий банк, який взаємодіє зі своїми клієнтами переважно через цифрові канали онлайн-банк [14].

Аналіз свідчить про те, що моделі А та В можна характеризувати як типові форми цифрових банків, тоді як моделі C та D вже відповідають принципам організації та функціонування онлайн-банків. Зазначимо, що на практиці онлайн-банки спеціалізуються, переважно, на обслуговуванні фізичних осіб і малого бізнесу. Тому завдяки масштабу, бренду, широкій клієнтській базі тощо переваги поки що мають традиційні банки. Однак ситуація стрімко змінюється, і вже прослідковується тенденція до заміни традиційних банків цифровими та онлайнбанками, які набувають все більше й більше переваг.

Аналіз особливостей цифрової трансформації банків свідчить про те, що головними проблемами, які стримують цей процес в Україні, є:

- недостатній рівень законодавчого та нормативного врегулювання діяльності цифрових і онлайн-банків;

- недостатнє розуміння керівниками банків необхідності та безальтернативності переходу на цифрові технології; 
- наявність регуляторних ризиків через недостатній рівень регулювання діяльності, що наражає цифрових і онлайн-банків;

- недостатній рівень надійності інфраструктури цифрового банкінгу;

- низька пропускна спроможність i недостатній рівень безпеки комунікаційних каналів;

- високий рівень конкуренції з небанківськими фінансовими установами та IT-компаніями;

- низький рівень довіри клієнтів до банківських установ $[15$, c. 538].

3 метою розв'язання цих проблем необхідним є розроблення та впровадження нових законодавчих і нормативних документів, a також забезпечення надійності функціонування нових цифрових технологій та їх захист від кіберзагроз і шахрайства.

\section{Література:}

1. Лютий I.O., Міщенко В.І. Проблеми розвитку сучасного міжнародного фінансового ринку та інтеграційний курс України. Фінанси Украйни. 2006. № 5. C. 21-31.

2. Міщенко В.І., Науменкова С.В. Банківська система України: проблеми становлення та розвитку. Фінанси Украӥни. 2016. № 5. С. 7-33.

3. Міщенко С.В. Проблеми забезпечення ліквідності банків на основі використання механізмів рефінансування. Фінанси Украӥни. 2009. № 7. С. 75-88.

4. Науменкова С., Міщенко С. Нові тенденції в монетарній політиці та діяльності центральних банків у посткризовий період. Банківська справа. 2011. № 5. C.12-29.

5. Науменкова С.В., Міщенко В.І. Поняття системного ризику та підходи до визначення системно значущих банків. Соціально-економічні проблеми сучасного періоду України. 2014. Вип. 1 (105). С.186-196.

6. Жупанин В.В., Міщенко В.I. Організація залучення заощаджень населення на основі випуску казначейських зобов'язань. Фінанси Украӥни. 2008. № 2. C. $44-58$.

7. Науменкова С.В., Мищенко С.В. Регулирование денежного обращения на основе использования методов и инструментов денежно-кредитной политики. Вісник Київського начіонального університету імені Тараса Шевченка. Економіка. 2013. № 6 (147). С. 66-72.

8. Науменкова С.В., Міщенко С.В. Інституційний розвиток фінансового сектору України. Фінанси України. 2008. № 7. С. 53-71. 
9. Кротюк В.Л. Еволюція підходів до оцінки капіталу в Базельських угодах. Банківська справа. 2005. № 4. С. 3-9.

10. Міщенко С. Сутність економічного капіталу та його роль у забезпеченні фінансової стійкості банку. Вісник НБУ. 2008. № 1. С. 58-64.

11. Науменкова С.В. Проблемы сбалансированности денежного рынка Украины. Київ : Наукова думка, 1997. 55 с.

12. Міщенко В.I., Науменкова С.В. Сучасні проблеми капіталізації банківської системи. Фінансово-кредитна діяльність: проблеми теорії та практики. 2013. № 2. С. 3-11.

13. Сенищ П.М., Кравець В.М. та ін. Світовий досвід та перспективи розвитку електронних грошей в Україні : науково-аналітичні матеріали; Центр наукових досліджень Національного банку України. Київ, 2008. Вип.10. 145 с.

14. Designing a sustainable digital bank. Learning from the digital pioneers. White Paper Executive Summary. IBM Corporation 2015. URL: https://www.ibm.com/downloads/cas/XGJGOJWA.

15. Єфименко T.I. Модернізація фінансової системи України в процесі євроінтеграції: монографія : у 2 т. / Т.І. Єфименко та ін. Київ, 2014. Т. 2. 781 с. 